\title{
THE EFFECT OF TRAINING AND WORKING FACILITIES TOWARDS CAREER DEVELOPMENT IN THE RESEARCH AND DEVELOPMENT DEPARTMENT OF LABUHAN BATU DISTRICT
}

\author{
Bayu Eko Broto \\ Dosen Fakultas Ekonomi dan Bisnis Universitas Labuhanbatu \\ Email : mail.to.bayueb@gmail.com
}

\begin{abstract}
This study aims to determine the effect of educating and training in career development at the Labuhanbatu Regency Research and Development Department, to determine the effect of work facilities in career development at the Labuhanbatu Regency Research and Development Department,. The results showed that educating and training had a positive and significant effect in career development at the Labuhanbatu Regency Research and Development Department, work facilities also had a positive and significant effect on career development in the Labuhanbatu Regency Research and Development Department. The result of multiple regression is $\mathrm{Y}=0.143+0.179 \mathrm{X} 1+0.806 \mathrm{X} 2$.
\end{abstract}

Keywords: Training, Working Facilities, Career Development.

\section{INTRODUCTION}

\section{Background of Problem}

In order to create good governance, that are law-abiding, transparent, accountable, and participatory government to be able to respond the changes that occur locally, nationally, regionally and globally, it is necessary to improve the governance system supported by professional apparatuses. No matter how perfect the technological and economic aspects are, without the human resources aspect, the organization's activities and objectives might not be achieved. Human resources is a living resource, which has mind, common sense, an attitude and way of thinking too. This is a very complicated problem for government agencies. Therefore government agencies must pay special attention to manage these resources. Dealing with these issues, the company needs management which can manage Human Resources carefully.

Many ways as the key to winning a commitment to success, government agencies offer their employees an opportunity to have a career, own and fill a successful career. Career development is one of the way. In case of career development, organizational members or employees who has lack knowledge of the conditions, requirements, levels and direction of careers in the organization. In such cases it is absolutely essential that there is complete information or explanation about career planning for the members concerned. In fact, sometimes they do not care about career problems, because the assumption that the management or leadership who have only thought and determined their policies. This is where each concerned organization must play an active role in carrying out the provision of the information, and guidance or counseling to those who need it. 
After a variety of information and guidance is given, determining one's career is the first step to know someone's career path. This is where the need to start thinking about the development of each of them, according to their abilities and skills. In this case helping the self-development of employees or members of the organization concerned. Career development is a person's personal efforts to achieve a career plan. Career development in a government agency is very important, because it can develop employees who are promoted, reduce employee turnover, encourage growth, etc.

Based on field observations, career development at the Labuhanbatu Regency Research and Development Department is still low. The source of information that researchers received was due to the fact that there were still employees who often postpone their works so that the work was not completed on time. In addition, there is also lack of training to support employee careers and inadequate facilities.

Factors that can improve career development include: teamwork, methods, mechanisms, incentives, and training and education. From some of the factors above and from the results of observations conducted by the researcher, training and working facilities are still low in the Labuhanbatu Regency Research and Development Department.

The influence of Education and Training (diklat) can improve the career development of an employee, both in handling current work and existing work in the future in accordance with the field of tasks carried in the organization. In addition, it must be equipped with experience, which has an important role in solving problems and obstacles experienced by employees in running the wheels of the organization in order to be more efficient and effective in achieving organizational goals. (Pormadi Simbolon, 2008.).

Based on the Minister of Home Affairs Regulation No.31 of 2007 concerning Guidelines for the Implementation of Education and Training in the Ministry of Home Affairs and Regional Government, one effort to realize a professional apparatus can be implemented through Education and Training (Diklat). Training activities are a process of increasing the competency of the apparatus to be able to produce optimal productivity through the transfer of certain knowledge, attitudes and skills to meet the requirements and are capable of carrying out their work.

Employee development is also very necessary in an agency, because with the program, it can help to improve the ability and skills of employees. Employee development is also designed to obtain employees who are able to make an achievement and be flexible for an agency in its future moves.

However, there are still various problems in Pre-service Training, especially in the implementation of Pre-service training, the main problem found in the aspects of participant characteristics is that the participation of Pre-service Training participants in general has not been realized by a deep desire to increase competence and lack of motivation of participants in following the training process. The reason for fulfilling the formality requirements for appointment as a civil servant is still often revealed in daily employee conversations. Learning activities are more about formality so that learning participation and adherence to the rules of training participants do not reach the optimal level of awareness.

Based on preliminary observations, several other problems, that are from the visible component of the facility, include inadequate work facilities, both facilities and infrastructure. The facilities and infrastructure used at the time of the Educating and Training activities are 
still far from the criteria, as explained by the Regulation of the Head of the State Administration Institution No.4 of 2007. So that the Educating and Training activities run less effectively.

The unavailability of adequate facilities will cause things that are not desirable and can be detrimental to the institution concerned. For example: the existence of strikes, absenteeism of employees increases, decreased employee productivity, and others, which in turn will decrease the productivity of the institution itself. So, leaders should understand what their employees need and know what desires that make employees satisfied and increase productivity.

With facilities means that the subordinates get the attention of their superiors, thus encouraging them to be passionate about working. Not only for that, the facilities provided to employees are also useful for achieving a better standard of living. The facilities provided are not only material, but material arts such as benefits in addition to basic salary (wages) such as holiday allowances and retirement benefits.

Training and facilities are important factors in improving someone's career development. Working facilities are the main requirements for productivity. Facilities allow someone to realize the tasks related to the required work to achieve goals. Whereas Training is an effort to improve the technical, theoretical, conceptual, and moral abilities of employees according to the needs of the job or position through education and training. For this reason, efforts by the government to support the improvement of employee career development by providing training and adequate facilities.

Based on these problems, in essence the implementation of Training in Labuhanbatu Regency is still not optimal, because there still needs to be improved, after all, Training (Diklat) is very influential on career development. Therefore the author wants to do research to see how much the Training and Working Facilities influence career development in the Department of Research and Development at Labuhanbatu Regency.

\section{Literature Review}

\section{Training}

Educating and training is a process of activities of a company that aims to improve and develop attitudes and behavior, skills and knowledge and intelligence of human resources in accordance with the wishes of the company concerned (Gorda, 2007).

Training is a process of company activities to improve employee mastery of various skills and techniques for carrying out specific, detailed and routine work and to improve and enhance knowledge, abilities, attitudes and personality traits (Handoko, 2007).

Training is a program that aims to improve the skills and techniques of implementing employee's work for current needs, as well as improvements in knowledge, knowledge, abilities, attitudes and personality to prepare employees ready to assume certain positions in the future (Umar, 2009).

According to Hasibuan (2008) the aim of the educating and training basically involves the following matters:

a) Work Productivity 
By training, employee productivity will increase, the quality and quantity of production will be better, because the technical skills, human skills, and managerial skills of employees are getting better.

b) Efficiency

Training aims to improve energy efficiency, time, raw materials and reduce the wear of machines. Waste is reduced so the production costs are relatively decrease.

c) Damage

Training aims to reduce the damage of goods, production and machinery because employees are increasingly skilled and talented in carrying out their work.

d) Accident

Training aims to reduce employee accident rates, so that the amount of medical expenses incurred by the company is reduced. e) Education and Training Services aims to improve better services to consumers.

e) Satisfaction

By training, employee's satisfaction will be better because their expertise and skills are in accordance with their work so that they are enthusiastic to get the job done well.

f) Career

By training, the opportunity to enhance employee careers is greater because their skills, skills and work performance are getting better.

g) Conceptual

By training, managers are more capable and faster in making better decisions.

h) Leadership

By training, leadership will be better, human relations are more flexible, motivation will be more directed so that vertical and horizontal cooperation will be more harmonious.

i) Reward services

By training, employee rewards will increase because their work performance is getting better.

j) Consumers

Training for employees will provide good benefits for consumers because they will get higher quality goods or services.

The benefits of the training program can be felt by organizations, individuals and staffing. According to Sirait (2008) the benefits of training are:

a) For organizations:

(1) Improve knowledge about position and skills.

(2) Improve work morale.

(3) Recognize the goals of the organization.

(4) Creating a better image of the organization.

(5) Improve the relationship between superiors and subordinates.

(6) Helping employees to adjust the changes.

(7) Helps to deal with conflicts in order to prevent stress and high tension.

(8) Helps improve productivity and quality of work. 
b) For Individuals:

(1) Helping individuals to be able to make decisions and solve problems better.

(2) Internalization and operationalization of work motivation, achievement, responsibility and progress.

(3) Enhancing self-confidence and self-development.

(4) Helps to reduce the fear of facing new tasks.

c) For Staffing:

(1) Improve communication between groups with individuals.

(2) Better understand about organizational policies, rules, and so on.

(3) Build a sense of closeness in the group.

(4) Creating an organization as a good place to work and live in it.

(5) Factors which enhance the training program.

\section{Facility}

Working facilities are a form of government service for employees to support the performance of employee based on their needs, in order to increase employee productivity. (Koyong, 2011).

Working facilities related to the work environment, because the work environment is also a working facility, with a comfortable work environment, employees can perform their work well. According to Moekijat (2006) simply what is meant by facilities is a physical facility that can process an input to the desired output. Furthermore according to Buchari (2007) the facility is a provider of physical equipment to provide convenience to its users, so that the needs of users of these facilities can be fulfilled. Added by Bary (2006) work facilities are a means given by the company to support the company's tone in achieving the goals set by the control holder.

According to Heijdarahman Ranu Pandjojo and Saud Husnan (2006), "services that provide facilities are activities that normally need to be managed by the employees themselves in their daily lives". Meanwhile according to Tjiptono (2006) facilities are physical resources that must exist before a service is offered to consumers.

Working facilities in each company are different in their form and type depending on the type of business and the size of the company. According to Alex S. Nitisemito (2008) the types of fun facilities can be interpreted widely including cafeteria recreation areas, sports venues, medical centers, places of worship, clean toilets, education for children and so on.

Facility indicators according to Faisal (2005) are:

1. Based on the need,

2. Able to optimize working results,

3. Easy to use,

4. Speed up the working process,

5. Placement is arranged properly.

\section{Career Development}


According to Simamora (2009: 188) the career development process in a formal approach is taken by the organization to ensure that people with the right qualifications and experience are available when they needed. So that career development can be mentioned to be a condition that shows an increase in the status of someone in the organization in the career path that has been set in the organization concerned.

Beside that, there is a career management of the organization to direct and control employee career paths. Because this relates to employee development, the career planning function sets goals for systematic employee development. So that the career goals of individual employees have been approved, development activities can be chosen and carried out in a direction that is meaningful both to individuals and to the organization.

Based on the above notions, it appears that career development must be passed through the preparation of prerequisites that must be possessed by an employee to support career advancement. The prerequisites are mutually supportive, in the sense that every career advancement of an employee must go through several predetermined criteria such as achievement, job / job weight, job vacancies, efficiency and others.

Beside that, the success in career development which means employees are making progress in working to improve skills so that they will be more skilfull. As Moekijat said, the most important thing in a position is:

1. Opportunity to do something that makes employees happy.

2. The opportunity to achieve something valuable.

3. Opportunities to try new things.

4. Opportunities to develop skill abilities.

Dealing with the principle of coaching based on work performance employee career development is done through promotions and appointments in positions. The willing of human resources in the organization to work efficiently and effectively, so not causing boredom at work, it is necessary to have a career development that includes; mutation, promotion, demotion.

According to Hasibuan (2009: 112), mutation is a change in position / position / place / work which done both horizontally and vertically (promotion / demotion) in an organization. The principle of mutation is to transfer employees to the right position and the right job, so that the enthusiasm and productivity of their work increases, which aims to improve the efficiency and effectiveness of work within the company. Mutation is one of the follow-up actions carried out from the results of work performance appraisal. With the mutation is expected to provide job descriptions, the nature of work, work environment, and work tools that are suitable for the employee concerned so that he can work efficiently and effectively in the position.

Based on the analysis above, career development is an approach or activity which is formally structured to increase growth, job satisfaction, knowledge and ability of employees so that the organization can ensure that people with suitable qualifications and experience are available in the organization.

The planned career development program contains three main elements: (Mokijat, $2009 ; 145)$

1. Assist employees in assessing their own internal career needs.

2. Develop and announce the career opportunities that exist in the organization. 
3. Adjusting the needs and abilities of employees with their career opportunities.

\section{RESEARCH METHODS}

\section{Technique of Data Collection}

Data collection techniques used in this study are as follows:

\section{Interview}

Interviews conducted using unstructured interviews because they only want to get additional information or an outline of the problem from respondents who have filled out the questionnaire.

\section{Library Research}

At this stage, the researcher seeks to obtain as much information as possible as a basis for theory and reference in processing data by reading, studying, studying, and studying the literature in the form of books, journals, papers, and previous studies related to the problem under the study.

\section{Internet Research (Online Research)}

Data collection comes from related sites to obtain additional literature, journals, and other data.

\section{Types and Sources of the Data}

In order to make this research to get maximum results, the types of data used are:

1. Qualitative data, which is data obtained in the form of both oral and written information. Data obtained from interviews, observations, and literature.

2. Quantitative data, which is data obtained in the form of figures that can be calculated. This data was obtained from a questionnaire that would be distributed and related to the problem under this study.

Based on the source, the data collected by the author can be divided into two types, they are:

\section{Primary Data}

Data obtained directly from the agency under this study, through observation and distribution of questionnaires. The data collected is qualitative in the form of data which relating to education and training, work facilities and work productivity.

\section{Secondary Data}

Data collected by the authors from documents in the company, from the results of library research, and from other relevant companies. This data is in the form of a general description of the company, such as its history, organizational structure, job descriptions and responsibilities.

\section{Data Analysis Method}


The analytical method used in this study is the Ordinary Least Square (OLS) Method. This is used to see the elasticity of the independent variables on the dependent variable of this study by using an analysis tool to process data using the SPSS program version 20.0.

Multiple regression analysis is used to process the data. Multiple regression analysis is used in calculating how much influence the dependent variable to the independent variable. The multiple regression analysis formula is as follows:

$$
\mathrm{Y}=\mathrm{a}+\mathrm{b}_{1} \mathrm{x}_{1}+\mathrm{b}_{2} \mathrm{X}_{2}+\mathrm{e}
$$

Information:

$\mathrm{Y}=$ dependent variable (working productivity)

$\mathrm{X} 1=$ independent variable (training)

$\mathrm{X} 2=$ independent variable (work facility)

$\mathrm{a}=$ constant

$\mathrm{b} 1, \mathrm{~b} 2$ = regression coefficient

$\mathrm{e}=$ Standard Error

\section{Coefficient of Determination (R2)}

The coefficient of determination is a statistical value that can be used to determine whether there is an influence relationship between two variables. The coefficient of determination shows the percentage variation in the value of the dependent variable that can be explained by the resulting regression equation. The magnitude of the percentage of the effect of all independent variables on the value of the dependent variable can be seen from the magnitude of the coefficient of determination ( $\mathrm{r} 2$ ) of the regression equation. The magnitude of the coefficient of determination is 0 to 1 , the closer to 0 the magnitude of the coefficient of determination ( $\mathrm{r} 2$ ) of a regression equation, the smaller the effect of all independent variables on the value of the dependent variable. Conversely, the closer to 1 the magnitude of the coefficient of determination ( $\mathrm{r} 2$ ) of a regression equation, the greater the effect of all independent variables on the dependent variable.

\section{Partial Hypothesis Testing (t Test)}

According to Sugiyono (2012), to examine the regression coefficients partially to find out whether the independent variables individually affect the dependent variable used the $t$ test with the formula.

$$
\mathrm{T}_{\text {count }}=\frac{b}{s b}
$$

Where :

$\mathrm{b}=$ estimated parameter of $\mathrm{X}$

$\mathrm{sb}=$ Standard error $\mathrm{X}$

Testing is done through $t$ test by comparing tcount with $t$ table at $\alpha 0.05$. if the calculation results show:

1. Ha: $b 1=b 2=0$ then Ho is accepted and Ha is rejected

This means that the variation of the independent variable cannot explain the dependent variable and there is an influence between the two variables tested. 
tcount <ttable, significant> $\alpha$ then Ho is accepted and Ha is rejected 2. Ha: $b 1=b 2 \neq 0$ then Ho is rejected and Ha is accepted

This means that the variation of independent variables can explain the dependent variable and there is an influence between the two variables tested.

$\mathrm{t}$ arithmetic $>\mathrm{t}$ table, significant $<\alpha$ then Ho is rejected and $\mathrm{Ha}$ is accepted.

\section{Testing Hypotheses Simultaneously (Test F)}

Concurrent test or F-test to examine if the independent variable simulatan has a significant or not significant effect with the dependent variable, the steps are as follows:

a) Make a hypothesis formula

1) H0: Which means there is no significant effect between the independent variables $(X)$ simultaneously, with the dependent variable (Y).

2) H1: Which means there is a significant influence between the independent variable (X) simultaneously, and the dependent variable (Y).

b) Determine the real level $(\alpha)$ and F table

- The actual level used is usually $5 \%(0.05)$ or $1 \%(0.01)$

- The F value of the table has free degrees $(\mathrm{db}), \mathrm{v} 1=\mathrm{m}-1$; v2 $=\mathrm{n}-\mathrm{k}-1$

$\mathrm{k}=$ number of independent variables, $\mathrm{m}=$ number of variables, $\mathrm{n}=$ number of samples

c) Determine testing criteria

1) $\mathrm{H} 0$ is accepted ( $\mathrm{H} 1$ is rejected) if $\mathrm{F} 0 \leq \mathrm{F} \alpha$; (v1) (v2)

2) $\mathrm{H} 0$ is rejected ( $\mathrm{H} 1$ is accepted) if $\mathrm{F} 0>\mathrm{F} \alpha$; (v1) (v2)

d) Look for a statistical test value (F0 value)

$$
\text { F-count }=\frac{\mathrm{R}^{2} / \mathrm{K}}{\left(1-\mathrm{R}^{2}\right) /(\mathrm{n}-\mathrm{k}-1)}
$$

Where :

$\mathrm{Fh}=\mathrm{F}$-count

$\mathrm{R}=$ multiple correlation coefficient

$\mathrm{n}=$ Number of data (respondents)

$\mathrm{k}=$ Number of variables.

e) Make conclusions

Conclude that $\mathrm{H} 0$ is accepted or rejected

\section{Classic Assumption Test}

a) Multicollinearity Test

Multicollinearity can be seen from a) the value of tolerance and the opposite b) variance inflation factor (VIF). The cutoff value that is commonly used is a tolerance value of 0.10 or equal to VIF above 10 (Ghozali, 2009).

b) Heteroscedasticity Test

If the residual value is not the same for all data, symptoms of heteroscedasticity occur. If the variable residual value is bigger, when the amount of data is added, then heteroscedasticity is ensured. Regression analysis requires that the variable residual value must be the same (homoscedasticity). Symptoms of heteroscedasticity are detected by graph analysis and looking at the scatter plot of the regression output where the $\mathrm{Y}$ axis is the predicted $\mathrm{Y}$, and the $\mathrm{X}$ axis is the residual (the actual Y-predicted Y).

c) Test for normality 
Another requirement for the use of regression analysis is that the data must be normally distributed, which is all data distribution approaches average and forms a normal curve. The data distribution will be close to the regression line or diagonal line. The graph can be seen in the normal plot graph (P-P plot) on the SPSS results. If the data are not normally distributed, then most data will be far from the average and there will be extreme data. This will make it difficult to make predictions. Data which are normally distributed will give a smoother and more accurate regression results (Ghozali, 2009).

Once the multiple regression model is known to get good prediction results or can provide benefits correctly, then the data analysis can be continued.

\section{RESEARCH RESULTS AND DISCUSSION}

\section{Inferential Statistical Analysis}

\section{Results of Regression Equations}

This analysis was used to determine the effect of independent variables (training and working facilities) on the dependent variable (career development). The results of computer processing can find out the equation of the multiple linear regression coefficients obtained as follows:

\section{$Y=0,143+0,179 X_{1}+0,806 X_{2}$}

The multiple regression equation is explained as follows:

1. A constant value of 0.143 means that if the training (X1) and working facilities (X2) are both fixed at zero, the productivity $(\mathrm{Y})$ produced is 0.143 .

2. Training had a positive and significant effect on productivity with a regression coefficient of 0.179 . This means that if training increases 0.179 then productivity will also increase by 0.179 .

3. Working facilities had a positive and significant effect on productivity with a regression coefficient of 0.806 . This means that if the work facility is 0.806 , productivity will also increase by 0.806 .

\section{Coefficient of Determination (R2)}

This analysis was used to find out how much the contribution or influence of the independent variables on the dependent variable is indicated by a percentage. The coefficient of determination (R2) shows the amount of contribution of the influence in the independent variable toward the dependent variable. The results of calculations that show the value of $\mathrm{R} 2=$ 0.791 . This means that $79.10 \%$ of productivity was influenced by training and working facilities while the remaining $20.90 \%$ was influenced by other variables which were not examined.

\section{Hypothesis Test}

Based on research data collected for both the dependent variable (Y) and the independent variables (X1 and X2) which were processed with the help of the SPSS program version 20.0 simultaneous significant test (f-test) and partial significant test (t-test) as follows:

\section{Partial Test ( $t$ test)}


This analysis was used to determine the significance level of the effect of independent variables toward dependent variable partially. $T$ test results are as follows:

1. The calculation results obtained $t$ value (1.848)> from $t$ table (1.688) then Ho was rejected and Ha was accepted, so the training variable had a significant effect on career development. 2. The calculation results obtained $t$ value (7.641)> from $t$ table (1.688) then Ho was rejected and $\mathrm{Ha}$ was accepted, so that the work facility variable significantly influenced career development.

\section{Concurrent Test (F Test)}

The $\mathrm{F}$ test was used to determine the significance of the influence of the independent variables together toward the dependent variable. The calculated $F$ value (119.139)> from the F table value $(2.87)$ with a significant value of $0.000<0.05$ then Ho was rejected so that there was a significant effect of training and working facilities simultaneously toward career development.

\section{Classic assumption Test}

This test was used to determine whether in a regression model, the dependent variable had a normal distribution or not.

\section{Multicollinearity Test}

Multicollinearity test was used to examine the existence of a perfect linear relationship (near perfect) between some or all independent variables.

Basic decision making based on tolerance values:

a. Tolerance $>0.1$ then there is no multicollinearity

b. Tolerance $<0.1$, multicollinearity occurs

Basic decision making based on VIF values:

a. VIF $<10$, multicollinearity does not occur

b. VIF> 10 then multicollinearity occur

From the multicollinearity test table it is known that the tolerance value of training was 0.355> 0.1 , so there is no multicollinearity, work facilities were $0.355>0.1$, so there is no multicollinearity.

Based on multicollinearity test, it is known that the VIF value of the training was $2.820<10$, so there is no multicollinearity, the VIF value of working facilities was $2.820<10$, so there is no multicollinearity.

\section{Heteroscedasticity Test}


Heteroscedasticity test was used to detect whether in the regression model occured an unequal variance from the residuals of one observation to another.

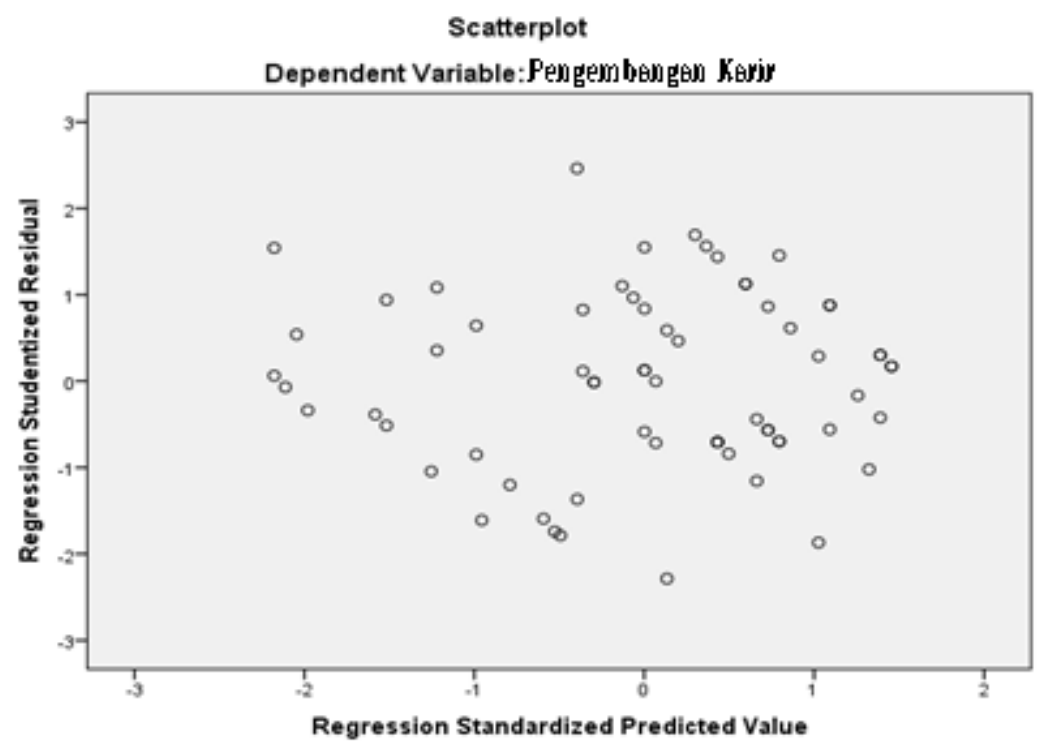

From the picture above it can be seen that the existing points did not form a certain pattern such as the points spread above and below the number 0 on the $\mathrm{Y}$ axis, then there is no heteroscedasticity.

The results of testing the coefficient of training on career development had a positive path of 0.179 which means more training will improve career development.

The results of testing the coefficient of work facilities on career development had a positive path of 0.806 which means the better the working facilities will improve career development. Variable of training and work facilities simultaneously had a significant effect on career development that was equal to 119,139 . The amount of influence of training and working facilities on career development was $79.10 \%$. While the remaining $20.90 \%$ was influenced by other variables which are not examined.

From the regression equation $\mathrm{Y}=0.143+0.179 \mathrm{X} 1+0.806 \mathrm{X} 2$ showed that the work facility variable had more influence on career development.

\section{CONCLUSION}

The results of research and discussion of the influence of training and working facilities on career development, the researcher draw conclusions:

1. Training has a positive effect with a regression coefficient of 0.179 with a tcount of 1.848 and a significant value of 0.000 , which means less than $0.05 .(0,000<0.05)$ towards career development.

2. Working facilities have a positive effect with a regression coefficient of 0.806 with a tcount of 7.641 and a significance of 0.000 , which means less than $0.05 .(0,000<0.05)$ towards career development.

3. Simultaneously training and working facilities have a positive and significant effect on career development. 


\section{REFERENCES}

Barry, Cushway, (2006), Human Resoure Management. Jakarta. PT. Elex Media Kumputindo.

Buchari Alrad, (2007), Manajemen Pemasaran dan Pemasaran Jasa. Bandung. CV. Alfabeta.

Davis, Keith dan Newstorm, J.W, 2005 Perilaku dalam Organisasi, Edisi Kesebelas, Diterjemahkan oleh Agus Dharma, Penerbit: Erlangga, Jakarta

Faisal, (2005) pengaruh insentif dan fasilitas kerja terhadap produktivitas karyawan. (http://repository.usu.ac.id/bitstream /123456789/pdf)

Hasibuan, Malayu, ( 2008 ), Manajemen Sumber Daya Manusia. Jakarta. Bumi Aksara.

Henry Simamora, (2008), Manajemen Sumber Daya Manusia, Penerbit STIE YKPN, Yogyakarta.

Husein Umar, (2009), Riset Sumber Daya Manusia Dalam Organisasi, Penerbit PT. Gramedia Pustaka Utama, Jakarta.

I G. N. Gorda, (2007), Manajemen Sumber Daya Manusia, Penerbit Astabrata Bali, Denpasar. Imam Ghozali, (2009), Aplikasi Analisis Multivariat dengan Program SPSS, Badan Penerbit Universitas Diponegoro, Semarang.

Moekijat, ( 2000 ), Manajemen Personalia dan Sumber Daya Manusia. Jakarta. Pustaka.

Ranupandojo, Heidjrachman dan Suad Husnan, 2006. Manajemen Personalia,

BPFE-UGM, Yogyakarta

Sinungan, Muchdarsyah, ( 2005 ). Produktivitas. Jakarta. Bumi Akasa

Sofyan Syafri, ( 2007 ). Manajemen Kontemporer. Jakarta. Edisi Pertama Grafindo Persada.

Soekidjo Notoatmodjo, (2008), Pengembangan Sumber Daya Manusia, Penerbit Rineka Cipta, Jakarta.

Sugiyono, 2012. Metode Penelitian Bisnis, Penerbit Alfabeta, Bandung

T. Hani Handoko, (2007), Manajemen, Edisi 2, Penerbit BPFE, Yogyakarta. Justine

T. Sirait, (2008), Memahami Aspek-Aspek Pengelolaan Sumber Daya Manusia Dalam Organisasi, Penerbit Grasindo, Jakarta. 